Open Journal System

Volume 1 no 12020

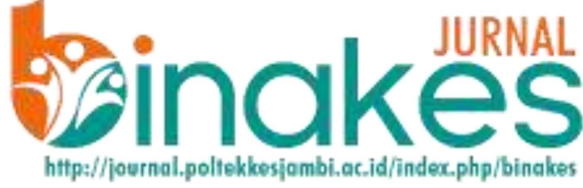

\title{
PENYULUHAN PENTINGNYA PEMERIKSAAN IVA PADA WUS (Wanita Usia Subur) DI DESA SUKAMAJU KABUPATEN MUARO JAMBI TAHUN 2018
}

Lia Artika Sari ${ }^{1}$, Enny Susilawati ${ }^{1}$

${ }^{1}$ Jurusan Kebidanan Poltekkes Kemenkes Jambi

\section{KONTAK PENULIS}

liaartikasari2021@gmail.com

DOI:

https://doi.org/10.35910/binake s.v1i1.368

\section{ABSTRAK}

Latar Belakang: Kanker merupakan salah satu penyebab kematian yang paling utama di dunia, sekitar 40 wanita tiap harinya terdiagnosa kanker leher rahim. Kanker leher rahim disebabkan oleh virus HPV, infeksi HPV sendiri sering kali tidak menimbulkan gejala. Desa Suka Maju merupakan salah satu desa yang terdapat di Kabupaten Muaro Jambi dan mempunyai jumlah wanita usia subur berjumlah 820 orang, namun hanya $17,11 \%$ wanita usia subur yang baru memanfaatkan pelayanan IVA.

Metode: Dengan memberikan penyuluhan kepada wanita usia subur dengan (WUS) sebanyak 40 orang, dan diberikan pre dan post test untuk mengevaluasi pengetahuan wanita usia subur mengenai pemeriksaan IVA

Hasil: terjadi kenaikan pengetahuan wanita usia subur di Desa Sukamaju sebesar $87,5 \%$.

Kesimpulan: Penyuluhan dapat meningkatkan pengetahuan wanita usia subur terhadap pentingnya pemeriksaan IVA . penyuluhan; pemeriksaan IVA; Wanita Usia Subur

\section{ABSTRACT}

Background: Cancer is one of the most common causes of death in the world. About 40 women are diagnosed with cervical cancer every day. Cervical cancer is caused by the HPV virus, HPV infection itself often causes no symptoms. Suka Maju Village is one of the villages in Muaro Jambi Regency that has 820 women of childbearing age, but only $17.11 \%$ of women of childbearing age bave just used IVA services.

Methods: employed in community service was to provide counseling to women of reproductive age with (WUS) as 40 women, and then given pre and posttests to evaluate the knowledge of women of childbearing age After being given counseling on IV A examinations. In brief,

\section{Keywords:}

counselling; investigation of IVA; women of childbearing age
Result: There was an increase in the knowledge of women of childbearing age in Sukamaju Village by $87.5 \%$.

Conclusion: Health education can increasedthe knowledge of women of childbearing age on the importance of IV A Chencking 


\section{PENDAHULUAN}

Kanker merupakan salah satu penyebab kematian yang paling utama di dunia. Kasus kanker leher rahim di Indonesia berkisar 15.000 kasus dalam kurun waktu satu tahun, hal ini mengungkapkan bahwasannya sekitar 40 wanita tiap harinya terdiagnosa kanker leher rahim. Kanker leher rahim disebabkan oleh virus HPV, infeksi HPV sendiri sering kali tidak menimbulkan gejala (Kementerian kesehatan RI, 2015).

Kanker leher rahim atau disebut juga kanker serviks adalah sejenis kanker yang 99,7\% disebabkan oleh human papilloma virus (HPV) onkogenik, yang menyerang leher rahim. Kelompok berisiko untuk terjadinya kanker serviks adalah wanita di atas usia 30 tahun yang memiliki banyak anak dan dengan perilaku menjaga kesehatan reproduksi yang masih kurang (Desby, dkk, 2015)

Ada banyak faktor yang mempengaruhi wanita usia subur tidak mau memeriksan diri guna mendeteksi adakan lesi pra kanker dengan menggunakan pap smear atau IVA, salah satunya kurangnya pengetahuan wanita usia subur akan pentingnya memeriksakan kesehatan organ reproduksi, ada rasa malu, tabu dan takut untuk memeriksakan diri ke petugas kesehatan, serta sumber informasi yang kurang dari petugas kesehatan. Menurut penelitian (Diah, dkk, 2018) terdapat pengaruh yang signifikan konseling edukasi terhadap pengetahuan WUS tentang kanker serviks dan IVA Test.

Provinsi Jambi sudah menggalakkan pemeriksaan IVA secara gratis di semua puskesmas, namun masih banyak juga wanita usia subur diwilayah tersebut belum mau memeriksakan diri dengan memanfaatkan pelayanan IVA secara gratis tersebut. Desa Suka Maju merupakan salah satu Desa yang terdapat di Kabupaten Muaro Jambi dan mempunyai jumlah wanita usia subur berjumlah 820 orang, namun hanya $17,11 \%$ wanita usia subur yang baru memanfaatkan pelayanan IVA. (Data Dinkes Muaro Jambi, 2017)

\section{METODE}

Metode dalam pengabdian masyarakat ini adalah dengan memberikan penyuluhan kepada wanita usia subur yang sudah menikah sebanyak 40 orang, dan sebelum diberikan penyuluhan wanita usia subur diberikan pre test untuk mengukur pengetahuan tentang pemeriksaan IVA dan setelah penyuluhan diberikan lagi post test untuk mengevaluasi hasil kegiatan.

Tahapan yang dilakukan sebelum melakukan penyuluhan yaitu berkoordinasi dengan Kepala Desa Sukamaju, Bidan dan Kader di wilayah setempat, menentukan jadwal mengumpulkan wanita usia subur, membuat satuan rencana penyuluhan, melaksanakan pre tes, melakukan penyuluhan, melakukan evaluasi berupa post tes.

\section{HASIL DAN PEMBAHASAN}

Kegiatan penyuluhan berjalan dengan lancar. Setelah diberikan penyuluhan mengenai pemeriksaan IVA terjadi kenaikan pengetahuan dimana sebelum diberikan ratarata pengetahuan wanita usia subur di Desa Sukamaju sebesar $50 \%$ dan setelah diberikan penyuluhan meningkat menjadi $87,5 \%$, hal ini dapat dilihat dalam tabel sebagai berikut:

Tabel 1. Pengetahuan WUS tentang pemeikasaan IVA

\begin{tabular}{lcc}
\hline Pengetahuan & $\begin{array}{c}\text { Jumlah } \\
\text { pengetahuan }\end{array}$ & $\%$ \\
\hline \multicolumn{3}{l}{ Sebelum Penyuluhan } \\
\hline Baik & 20 & $50 \%$ \\
Kurang Baik & 20 & $50 \%$ \\
\hline \multicolumn{2}{l}{ Sesudah Penyuluhan } \\
\hline Baik & 35 & $87,5 \%$ \\
Kurang Baik & 5 & $12,5 \%$ \\
\hline
\end{tabular}

Pengetahuan mendasari seseorang dalam mengambil keputusan, dimana seseorang yang memiliki pengetahuan akan mudah menentukan keputusan yang terbaik untuk dirinya dan mengatasi masalah yang dihadapi dalam hal ini khususnya masalah kesehatan. Yang mempermudah terjadinya perilaku seseorang, terwujud melalui 
pengetahuan dimana pengetahuan tersebut mendasari seseorang untuk mengambil keputusan dan menentukan tindakan terhadap masalah yang dihadapi Notoatmojo (2010).

Hasil Penelitian Julianti (2016) menyatakan kurangnya pengetahuan tentang IVA menjadi alasan utama seseorang belum melakukan pemeriksaan IVA. Ketidaktahuan responden dilatarbelakangi adanya informasi yang tidak tersampaikan dari tenaga kesehatan melalui kader kepada masyarakat.

Hasil kegiatan ini sejalan dengan penelitian Febriani (2016) bahwa sikap wanita dewasa di wilayah Kabupaten Banyumas memiliki hubungan yang signifikan dengan pemeriksaan deteksi dini kanker serviks. Pada kegiatan pengabdian masyarakat tersebut sebagian besar individu yang hadir mempunyai pengetahuan, persepsi dan sikap yang positif terhadap suatu topik masalah kesehatan, maka untuk terjadi eksekusi perilaku kesehatan yang positifpun akan lebih besar.

Susanti, Aris (2010), mengatakan dukungan dari anggota keluarga juga bisa berpengaruh terhadap pemeriksaan IVA dalam deteksi dini kanker servik.

Masyarakat Desa Sukamaju sendiri masih takut untuk melakukan pemeriksaan IVA dikarenakan mereka malu untuk membuka alat kemaluan didepan petugas kesehatan, dan masih minimnya pengetahuan bagaimana cara pemeriksaan IVA itu sendiri membuat masyarakat enggan untuk melakukan pemeriksaan IVA.

Setelah adanya penjelasan dengan melalui penyuluhan dan dibuka sesi tanya jawab, wanita usia subur khususnya di Desa Sukamaju sudah mengetahui manfaat besar dari hasil pemeriksaan tersebut, dimana dengan melakukan pemeriksaan secara rutin dan dengan alat yang sederhana sangat bermanfaat untuk mendeteksi secara dini kanker leher rahim, hal ini sejalan dengan penelitian Yevin (2017) menunjukan bahwa meski pengetahuan cukup namun belum tentu PUS akan melakukan pemeriksaan IVA. Pengetahuan cukup ini bisa dilatar belakangi karena kemampuan dalam analisis pertanyaan.

Beberapa wanita usia subur tidak diizinkan oleh suami untuk melakukan pemeriksaan IVA dikarenakan suami menganggap membuka kemaluan didepan orang lain selain untuk melahirkan menjadi hal yang tabu atau membuat malu, Salah satu faktor yang memperkuat terjadinya perubahan perilaku, yaitu dukungan keluarga terdekat merupakan hal yang tidak dapat diabaikan (Notoatmojo, 2007)

\section{KESIMPULAN}

Pemberian pengetahuan dengan memberikan penyuluhan dapat bermanfaat mengubah pengetahuan seseorang menjadi lebih baik, dan menyadarkan wanita usia subuh untuk rutin mendeteksi kanker leher rahim dengan metode sederhana yaitu melalui pemeriksaan IVA.

Setelah memberikan informasi kepada wanita usia subur sendiri perlu adanya informasi yang harus diberikan kepada suami atau orang terdekat agar mendukung wanita usia subur untuk memeriksakan diri guna mendeteksi kanker leher Rahim.

\section{DAFTAR PUSTAKA}

Desby Juanda, Hadrians Kesuma. Pemeriksaan Metode IVA (Inspeksi Visual Asam Asetat) Untuk Pencegahan Kanker Serviks. Jurnal Kedokteran Dan Kesehatan, Volume 2, No. 2, April 2015: 169-174

Diah Lestari Nasution, Nur Asnah Sitohang, Cut Adeya Adella (2018). Deteksi Dini Kanker Servik Pada Wanita Usia Subur Dengan Inspeksi Visual Asam Asetat (Iva Test) Di Klinik Bersalin Kota Medan. Jurnal Riset Hesti Medan, Vol. 3, No. 2, Desember 2018

Febrina, Christine Angelina (2016). Faktor-Faktor Yang Berbubungan Dengan Deteksi Dini Kanker Leher Rabim Di Kecamatan Gisting Kabupaten Tanggamus Lampung

Kementerian Kesehatan RI (2013). Buku Acuan Pencegahan Kanker Payudara dan Kanker Leher Rabim, Jakarta.

Julianti, Ni Putu Irma (2016). Faktor-Faktor Yang Berbubungan Dengan Pemanfaatan Pemeriksaan Inspeksi Visual Asam Asetat Oleh Wanita Pasangan Usia Subur Di Puskesmas Mengwi I.

Notoatmojo S (2010). Promosi Kesehatan dan ilmu perilaku. PT Rineka Cipta. Jakarta.

Ropitasari., Soetrisno., Mulyani.S., Saddhono. K, 2014. Deteksi dini kanker leher rahim melalui tes IVA di Puskesmas Jaten II Kab. 
Karanganyar. Jurnal fakultas kedokteran Universitas Sebelas Maret;Vol 3 No 1 Nov 2014 Suryati Romauli, dkk (2009). Kesehatan Reproduksi buat Mahasiswi Kebidanan,Nuhamedika.

Susanti, Aris (2010). Faktor - Faktor Yang Berbubungan Dengan Rendahnya Kunjungan Inspeksi Visual Asam Asetat (Iva) Di Wilayah Kerja Puskesmas Halmahera Kecamatan Semarang Timur Tabun 2010

Taufan Nugroho (2010). Buku Ajar Ginekologi untuk. Mahasiswi Kebidanan.Nuhamedika.

Yevin, Brida Kity Dinarum Vina Walno (2017). Faktor- Faktor Yang Berbubungan Dengan Pemeriksaan Deteksi Dini Kanker Serviks Metode Inspeksi Visual Asam Asetat (Iva) Di Wilayah Kerja Puskesmas Buayan Kebumen 